This is an electronic reprint of the original article. This reprint may differ from the original in pagination and typographic detail.

Author(s): Sippola, Markku; Kall, Kairit

Title: $\quad$ Locked in Inferiority? : The Positions of Estonian Construction Workers in the Finnish Migrant Labour Regime

Year: $\quad 2017$

Version:

Please cite the original version:

Sippola, M., \& Kall, K. (2017). Locked in Inferiority? : The Positions of Estonian Construction Workers in the Finnish Migrant Labour Regime. In J. E. Dølvik, \& L. Eldring (Eds.), Labour Mobility in the Enlarged Single European Market (pp. 215-240). Emerald Group Publishing Limited. Comparative Social Research, 32. https://doi.org/10.1108/S0195-631020160000032009

All material supplied via JYX is protected by copyright and other intellectual property rights, and duplication or sale of all or part of any of the repository collections is not permitted, except that material may be duplicated by you for your research use or educational purposes in electronic or print form. You must obtain permission for any other use. Electronic or print copies may not be offered, whether for sale or otherwise to anyone who is not an authorised user. 


\title{
Locked in inferiority? The positions of Estonian construction workers in the Finnish migrant labour regime
}

Markku Sippola and Kairit Kall

\begin{abstract}
The aim of this article is to analyse how different policies and actors have structured the current migrant labour regime in the Finnish construction sector and to discuss the consequences for migrants. Our study shows that a strong industrial relations system such as in Finland is able to curb the posting of workers regime (the most disadvantageous for migrant workers). The position of labour migrants has become more diverse in the segmented labour market, although it remains inferior compared to that of the natives. Consideration of the policy development revolving around the changing migrant labour regimes constitutes the first part of the analysis and is based on government and trade union officials' accounts. The more substantial part of the study draws upon biographical interviews with Estonian construction workers and analyses the division of migrant labour according to their employment in four 'patterns of firm ownership' that range from the most unfavourable to most favourable position: workers posted by Estonian firms; workers employed by firms registered in Finland but operated by Estonians; self-employed/small business owners; and workers employed by Finnish firms. The structuring of the regime according to the pattern of firm ownership can be interpreted as a manifestation of employers' intentional strategies to adapt to or avoid national regulations and to some extent as also reflecting workers' individual and collective agency.
\end{abstract}

\section{Introduction}


This study, which draws upon biographical interviews with Estonian construction workers working in Finland and expert interviews with union and government officials, analyses the emerging migrant labour regime in the context of the large inflow of Estonian construction workers to Finland. Firstly, it elaborates on the structuring of the regime and shows that labour market regulations and industrial relations are crucial in shaping it. Secondly, it aims to show the differing position of migrant workers within the regime, which is contingent upon their employment in different patterns of firm ownership. Although some studies have shed light on the internal division of segmented migrant labour regimes (e.g., Fan 2002; Colic-Peisker \& Tilbury 2006; Friberg 2012; Wills et al. 2009), to our knowledge there is no previous scholarly attempt to grasp the internal variation of the migrant labour market regime on the basis of workers' employment in firms with different ownership types within one nation-state and taking a particular sector as an example. This study seeks to fill this void. Based on biographical interviews with workers, we consider firm ownership as an important factor contributing to the segmentation of employment conditions.

Prior to the accession of 10 Central and Eastern European (CEE) countries to the European Union (EU) in 2004, the Central Organisation of Finnish Trade Unions (SAK) warned that there would be 400,000 Estonian workers coming to the Finnish labour market if no restrictions on free mobility were imposed. In Finnish 'corporatist' tradition trade unions, alongside the government and employer associations, play a major role in shaping national industrial relations (Sippola 2015). Significantly influenced by the opinion of the SAK, the Finnish government used the option to impose a 2-year transition period on the free movement of labour (May 2004- April 2006), during which time the mobility of workers to Finland occurred mainly in the form of the posting of workers. This policy choice had peculiar consequences for the Finnish construction labour market (unintended by the unions): 
hundreds of Estonia-based construction firms were established in order to provide services for Finnish main contractors, while the conditions of labour in this 'posting of workers' regime varied between Estonian and Finnish standards. The regime that emerged placed a huge burden on labour market actors, including trade unions and labour inspectors, endeavouring to monitor the fulfilment of the conditions of labour agreed upon among the Finnish labour market parties. Reports on breaches of the Labour Code were regularly seen in the media; labour inspectors as well as union officials provided numerous accounts of violations of labour conditions on the part of Estonia-based service providers.

Worker posting has proven to undermine strong industrial relations systems in Europe (Wagner \& Lillie 2014). This is a European-wide problem, where the nexus of subcontracting, transnational mobility, legal insularity and employer anti-unionism complicate union and legal enforcement of labour market standards (Berntsen \& Lillie 2014; Eldring, Fitzgerald \& Arnholtz 2012). The 'posting of workers' regime remained widely used in the Finnish construction sector for many years after the lifting of the restrictions on free movement of labour in 2006. Posted work gave employers the means to 'opt out' of national regulation (Lillie \& Sippola 2011). However, a change towards a greater variety of employment relationships has occurred in the 2010s. The use of posted workers from Estonia has lost its attractiveness for companies, as the 'beating of the system' has become more difficult. This has occurred mainly due to deliberate politics by the Finnish government, which have been influenced by social partners. Today, there are signs that the policies of the government aimed at regulating the construction sector have had a positive overall effect on the construction labour market. This suggests that even within the single EU labour market, certain (strong) national industrial relations systems are more resistant to the corroding effects of post-accession labour migration than others. 
Based on our data we elaborate on the internal division of the current migrant labour regime and introduce the notion of 'pattern of firm ownership'. It refers both to the distinct division of labour between main contractors with Finnish ownership and subcontractors with Estonian ownership and to the migrant workers' relationship with and distance to the main contractor. The pattern of 'firm ownership' is thus a conceptual short form that points to the fact that the Estonian migrants are incorporated into a system of production where staffing strategies and working conditions differ systematically in accordance with their employers' nationality, the relationship to the main contractor (and function in the production chain) and workers' contractual status.

Accordingly, a major part of the analysis concerns the division of migrant labour according to four main patterns of firm ownership, ranging from the most unfavourable to the most favourable position for the Estonian workers: posting of workers; employed by a firm registered in Finland but operated by Estonians; self-employed/small business owners; and employed by Finnish firms. The sequence of the presentation of these different positions is based on the observed ranking of precariousness (in terms of uncertainty) and the level of wages of the various positions. We also argue that even though it is possible for Estonian construction workers to end up in a rather secure employment situation, they mostly remain in positions materially inferior to and culturally detached from those of natives.

The article is structured as follows. First, in the theory section foundations for the different regimes for natives and migrants are presented, including the factors structuring the evolving migrant labour regime in Finland. The second section familiarises the reader with the Finnish construction sector. Then follows a methodology section, after which the making of the 
'migrant labour regime' - a heuristic concept emphasising political and relational grounds for labour migration - is elaborated on; this elaboration is mainly based on government and union officials' accounts. Section five describes the structure of the current migrant labour regime prevailing between Estonia and Finland and is based largely on worker biographies. The discussion and conclusion section sums up the findings and suggests issues for future research.

\section{Different labour regimes for natives and migrants}

In his seminal work Piore (2008 [1979]) developed the idea that labour markets in the advanced industrial economies are divided into two tiers. The migrant workforce occupies positions mainly in the lower one which is characterised by lower wages, inferior working conditions, less stability, lack of advancement opportunities and less autonomy than those in the first tier that are mainly occupied by natives. The uncertain and temporary nature of work in the lower tier is best captured by the concept of precariousness. According to Kalleberg (2009: 2), precarious work refers to 'employment that is uncertain, unpredictable, and risky from the point of view of the worker'. In a similar vein, Friberg et al. (2013: 112) conclude that rather than a lack of income, 'precariousness is related to lack of stability, security and control in one's employment situation'. Although precarious working conditions have become more widespread throughout the Western world during recent decades and are no longer only characteristic of migrant jobs, migrants tend to experience a higher degree of precariousness.

One cannot ignore the role of governmental and intergovernmental regulations in shaping the segmentation of the labour market. Here, the EU's principle of free movement of labour and 
services serves as an incentive for institutional changes at the national level; local state apparatuses, in their turn, serve as active progenitors of neoliberalisation 'from above' as they call for greater wage differences and the use of different standards for foreign subcontractors (Sippola 2012). The regulation by the nation state can also function in the opposite direction by curbing the effects of labour market flexibilisation through legislation. However, national and multinational employers as well as migrants themselves can still reinforce the flexibilisation tendency. As Meardi, Martín and Riera (2012: 7) argue:

Cross-border worker mobility, especially but not only within the EU, offers a possible solution to the problem of combining flexibility and security: the creation of a hyper-flexible buffer of migrant workers who, being disposable in case of downturn, can carry most of the uncertainty burden without causing political problems.

We argue that migrants more often than not indeed find themselves in less advantageous positions than natives, but the position of migrants is becoming diversified according to their employment status within the segmented labour market. This might especially be the case in Finland and other Nordic countries where the labour market is still rather highly regulated and employers try to find ways to gain competitive advantage by circumventing national regulations (Herrmann 2008; Lillie \& Sippola 2011) via, for example, employing migrant workers through foreign subcontractors. To fully capture the variation of employment statuses (in the labour market), and to incorporate the role of the state in the contemporary shaping of the labour market, we use the concept of labour market regime. The notion of 'regime' itself is based upon Elvander's (2002: 118) use of the term that embraces: 
...the totality of a country's labour market relations, from the workplace to the central political level where the political conditions for the development of labour relations are decided, such as general economic policy, labour market and incomes policies, labour law, etc. The scope and main direction of policies directed to the labour market will be an important element in comparisons between regimes or groups of regimes.

The regime concept has some parallels with concepts such as 'industrial relations (IR) systems' or 'IR models'. A difference between the IR concepts and the concept of 'labour market regime' resides in the fact that the latter attributes a more active role to the state. Furthermore, the labour market regime presupposes some degree of permanence and pathdependency. Historical trajectories have been essential in shaping the Nordic labour market regimes (Elvander 2002). Potentially, there is one important feature in the Finnish regime which might prevent some employers from circumventing national regulations: the legal extension of collective agreements. In this respect, Finland differs from the other Nordic countries, in particular Denmark and Sweden (e.g. Ebbinghaus 2004). The Finnish wage bargaining system is based on sectoral collective agreements which set industry minimums and in most sectors, including construction, are extended over the whole sector by government decrees. Thus, also workers employed in companies without collective agreements are covered by the minimum provisions set in the legally extended agreements. The conditions of sectoral collective agreements are also extended to posted workers; posted workers can also authorise trade unions to take legal action on their behalf against their home-country employer for not complying with the host-country's collective agreement. ${ }^{1}$

\footnotetext{
${ }^{1}$ An important preliminary ruling concerning this was made by the European Court of Justice in February 2015 (Case C-396/13 Sähköalojen ammattiliitto ry v Elektrobudowa Spółka Akcyjna).
} 
Our notion of migrant labour regime, however, cuts across the original concept as Elvander (2002) sees it, which makes our term more distinctive. We argue that the emerging EstonianFinnish migrant labour regime has dissimilarities with the Finnish labour regime for natives in two respects. Firstly, as those coming from outside into the Finnish labour market will often remain outsiders (culturally and economically), it is reasonable to speak in terms of a distinctive cross-border regime reserved for migrant labour. Secondly, as our definition of 'regime' also involves supranational (EU) regulation, it makes sense to differentiate between the labour regime for locals - which is mostly national by nature - and the labour regime for migrants - which entails quite a high deal of European, regulation.

The concept of a migrant labour regime provides the state and social partners with an active role. One proposition of this study is that in the host society the national regulations that are shaped by national legislation and social partners, in interplay with the supranational regulations, have a significant impact on the labour market position of migrants. As of 1 May 2004, Estonia joined the European Union. However, because of the Finnish 2-year transition period for free movement of labour, Estonian labour mobility to Finland mainly took the form of the posting of workers rather than individual migration. In May 2006, when the restrictions were lifted, the posting of workers remained a major form of labour migration. The financial crisis of 2007-2009 gave a major boost to individual emigration from all the Baltic countries, which was connected with the deteriorated social and labour conditions in these countries (Sippola 2013). Based on the interplay of regulations, employer and worker strategies, we argue that the regime has become more diversified and segmented according to the pattern of firm ownership, as it is no longer predominantly based on the posting of workers. 
The internal division of segmented migrant labour regimes has been scrutinised in Australian (Colic-Peisker \& Tilbury 2006), Norwegian (Friberg 2012) and Chinese (Fan 2002) contexts. Also, Wills et al.'s (2009) study on the division of migrant labour in London provides an important contribution to understanding the shaping of a local labour market regime in terms of migrant citizenship status, employer preferences and government regulation. An important observation by Wills et al. (2009) - which is also acknowledged in the present study - is that the regime undergoes constant changes due to intersecting decisions by the government, employers and workers. Our approach introduces the internal differentiation of the migrant labour market regime on the basis of one's employment in different patterns of firm ownership, which has not been elaborated on before, but according to our data is an important factor contributing to the segmentation of the regime.

\section{The construction sector in Finland}

In the following we will give a brief overview of structural features of the Finnish construction sector. There are around 170,000 employees in the sector, of whom 100,000 are in manual jobs; $20-25 \%$ of the latter are foreigners, around a third of whom are working in the Helsinki metropolitan area (Alho 2013). Estonians form the biggest foreigners' group in the construction sector (Statistics Finland 2013). The unionisation rate of migrant workers is relatively modest. Alho (2013) has calculated that in 2012 the unionisation rate among migrant construction workers was $12-14 \%$, which is far from the $70 \%$ rate prevailing in construction in general (Union official \#3).

International subcontracting and cross-border labour mobility, especially the posting of 
workers, have characterised the labour process of the construction industry in recent years (Lillie and Sippola 2011). This development has contributed to obscuring the main contractor's liability for the wage and working conditions at the lower end of the subcontracting chain. Thus, the main contractors are capable of evading the norms of the Finnish labour code by using foreign (mostly CEE, especially Estonian) subcontractors, who bring their own low-paid labour onto construction sites (Lillie and Sippola 2011; Sippola 2012). Foreign labour and especially workers posted from abroad as 'service providers' bring forth such circumstances on the sites that workers executing the same jobs can have different labour conditions and their social security contributions are made to different countries - or they are not made at all. Cases in point are as follows: the commuting of Estonian workers from Estonia to Finland, which has created a 'translocal' labour market in the construction sector (Alho 2013) and the use of Polish posted workers at Olkiluoto 3 construction site, which has turned the site into a 'space of exception' in regard to the Finnish industrial relations system (Lillie and Sippola 2011).

In recent years the Finnish government - first and foremost pushed by the construction union Rakennusliitto - has taken deliberate steps to reregulate the construction sector. Since January 2013, all construction workers are obliged to obtain a tax number, which has enhanced the controllability of construction sites. In July 2014, the so-called 'construction site register' and main contractor liability were introduced to get fuller access, for example, to hours worked and tax information of all individuals involved in a construction project. A change in the subcontracting chain management of the main contractors is visible: the posting of workers is no longer the most favoured form of operating in the Finnish construction sector. Instead, a new practice of prodding Estonian firms to register themselves in Finland can be seen. Earlier it was easier for both domestic companies and transnational firms to find 
alternative ways of circumventing institutional constraints at the national level (Herrmann 2008; Lillie \& Sippola 2011). We assume that these developments have had an effect on the restructuring of the migrant labour regime as well.

\section{Methodology}

This study applies a migrant-centred focus on studying the structure of the Finnish migrant labour regime. The analysis is mainly based on 18 biographical narrative interviews (Schütze, 2005) conducted during 2013-15 with Estonian men (as the sector is highly male-dominated) working in the Finnish construction sector (see Table 1). Although a couple of them were small business owners, they also worked in their own company as construction workers. In addition, we made 7 follow-up interviews 1.5-2 years later. Respondents were found through the personal contacts of the research group, snowballing and also social media.

Using workers' employment stories to examine the position migrants occupy in Finland is especially valuable as statistics about different forms of employment are either not available or not very reliable, given that companies often use illegal employment practices that are not reflected in the register data. The biographical approach also enables us to track the changes in the employment situation, analyse the meanings people give to them and examine what kind of barriers and opportunities migrant workers experience in the Finnish labour market. Importantly, these interviews provided us insight into the situation related to different kinds of employment arrangements and enabled us to construct the notion of 'pattern of firm ownership' that helps to understand the internal division of migrant labour regime.

Table 1: Overview of interviewed construction workers 


\begin{tabular}{|c|c|c|c|}
\hline Name & $\begin{array}{l}\text { Currently employed } \\
\text { by... }\end{array}$ & $\begin{array}{l}\text { Experience with being a } \\
\text { posted worker }\end{array}$ & $\begin{array}{l}\text { Years in Finland } \\
\text { (during first } \\
\text { interview) }\end{array}$ \\
\hline Mart* & $\begin{array}{l}\text { Estonian temporary } \\
\text { agency firm }\end{array}$ & Yes & $7-8$ \\
\hline Anti & $\begin{array}{l}\text { Finnish firm owned by } \\
\text { Estonians }\end{array}$ & Unclear** & 4 \\
\hline Timo & $\begin{array}{l}\text { Finnish firm owned by } \\
\text { Estonians }\end{array}$ & Unclear** & 6 \\
\hline Tom & $\begin{array}{l}\text { Finnish firm owned by } \\
\text { Estonians }\end{array}$ & Yes & 3 \\
\hline Aleksandr* & $\begin{array}{l}\text { Finnish firm owned by } \\
\text { Estonians }\end{array}$ & Yes & 3 \\
\hline Ragnar & $\begin{array}{l}\text { Finnish firm owned by } \\
\text { Estonians }\end{array}$ & Unclear** & 9 \\
\hline Aivar & $\begin{array}{l}\text { Finnish firm owned by } \\
\text { Estonians }\end{array}$ & $\begin{array}{l}\text { Most probably (at an } \\
\text { Estonian subcontractor } \\
\text { providing piping works) }\end{array}$ & 4 \\
\hline Evert & $\begin{array}{l}\text { Finnish firm owned by } \\
\text { Estonians }\end{array}$ & Unclear** & 4 \\
\hline Arno & $\begin{array}{l}\text { Finnish construction } \\
\text { firm }\end{array}$ & Yes & 4 \\
\hline Veiko & $\begin{array}{l}\text { Owner of a company } \\
\text { with } 3 \text { workers }\end{array}$ & Yes & Smaller periods \\
\hline Kalev & Owner of a company & No & Many years \\
\hline
\end{tabular}




\begin{tabular}{|l|l|l|l|}
\hline & with 11 workers & & \\
\hline Jaan* & Self-employed (2013), & Yes & 7 \\
Finnish construction & & \\
\hline Vello* & Finnish agency firm & No & \\
\hline Rein* & Finnish construction & Yes & 3 \\
\hline Edgar* & Firm & & $6-7$ \\
\hline Valdo & Firm & Yes & 3 \\
\hline Lembit* & Finnish construction & Unclear** & \\
\hline firm & firm & Yirm & \\
\hline
\end{tabular}

* Also follow-ups

** Often the workers themselves do not see a difference as to whether they are posted, agency workers or in a normal employment relationship; the blurred borders between 'posted' and 'normal' statuses have also been evidenced elsewhere (Eldring 2011).

Although the main body of the data builds on the migrants' views, we also wanted to include information on policy developments influencing the migrant labour regime. Therefore we contextualise the migrant experiences with 11 background expert interviews (conducted between spring 2014 and spring 2016) with Finnish government officials; embassy representatives; officials of the construction workers union Rakennusliitto; the Rakennusliitto 
representative in Tallinn; the Estonian labour inspector in construction; and the official from the Estonian labour inspectorate dealing with posted work regulation. Before going to the positioning of the workers in the evolving migrant labour regime, we will describe the development of the regime through accounts of the government and union officials.

\section{The making of the migrant labour regime: Government's deliberate strategy and construction companies' reactions to it}

This section, which is based on the interviews with the experts, concentrates on the drivers of regulation that have paved the way to the contemporary shape of the migrant labour regime. State regulation and structures - to which social partner institutions also contribute - are either enabling or constraining the activities of the primary labour market actors; that is, national and transnational employers and migrant workers. In order to understand the structure of the regime, it is also important to see how and by whom this regime is constituted.

During the 2-year transition period to the free movement of labour from May 2004 to April 2006, the mobility of workers to Finland mainly took the form of worker posting. Due to this policy, hundreds of Estonia-based construction firms were established in order to provide services for Finnish main contractors, while the conditions of labour in this 'posting of workers' regime varied between Estonian and Finnish standards. However, the regime has undergone changes since then, the main difference being the extent to which the posting of

workers has been used. One indicator of the trends in the posting of workers is the number of A1 portable documents issued by the sending country. The statistics of the Social Insurance Board of Estonia show that the number of A1 documents issued for Estonian companies 
sending their workers to Finnish construction sector peaked in 2011 (being 10,220 postings) and has declined since to 1,995 official postings in 2015 (Social Insurance Board 2015). These statistics do not show the full picture of the phenomenon, as not all companies apply for these forms, and some of the postings fall into the grey area, but they do indicate the major trends in the construction labour market.

Union officials' interviews provide background information about the change in the regime. After the introduction of tax numbers in the construction sector in 2013, there appeared $10,000-11,000$ more workers in the sector who turned their 'black' status into official employment (Union official \#1a). At the time of the interview, there were around 80,000 Estonians on the pension insurance register in Finland plus around 15,000 posted workers; these numbers included, however, workers from all sectors. However, the union official noted that the number of posted workers was decreasing in the construction sector, while Estonians seemed to have been given more permanent positions in enterprises (Union official \#1b).

Rakennusliitto's cooperation with the employers' association in the construction sector, the Confederation of Finnish Construction Industries RT, has been fruitful in initiating regulatory changes in the sector. This started with joint efforts in lobbying for the law on main contractor liability, followed by the reverse-charge VAT system and culminating in the introduction of mandatory tax numbers in the construction industry in 2013 (Union official \#2). Finally, the construction site register was introduced in summer 2014. Under the new system, the main contractor is liable to provide information for the tax authority on the employees, subcontractors' employees, sums of contracts and wage sums of the entire site. The union official (\#2) insisted that in this way the Finnish contractors, who do their work in accordance with the rules, will gain back the competitive advantage they have lost due to 
grey economy actors. In the official's (\#2) opinion, the tax numbers and main contractor's liability have worked well. What is more, the tax authority got more resources for inspections. Trade union officials have held regular meetings with tax officials, who are bound by their clauses of confidentiality but who are willing to listen to instances in which the trade union officials have discovered violations to the rules.

These observations seem to indicate that there are fewer posted workers from Estonia in the Finnish construction sector nowadays, because the Finnish government has taken strict measures against the grey economy. It is not easy, after all, to establish a company in Estonia and then provide services in Finland. And, further, if the posting of workers is done according to the rules, it is not economically very beneficial. In addition, Rakennusliitto has pressured Finnish main contractors not to use companies established in Estonia; and Estonian companies are not any more seen as very reliable by the main contractors. Neither can we exclude the effect of the economic crisis: Estonian firms are probably among those that lose their contracts first.

Simultaneously, with the decline in posting of workers from Estonia, there have been fluctuations in regard to Estonians establishing their own businesses in Finland. There was a peak at the beginning of the 2010s, when the main contractors started preferring Finnish companies as suppliers to Estonian ones; according to the municipality official (\#1), the change occurred because the customers of these contractors did not trust Estonian-looking company names. This did not imply distrust in Estonian workers per se but in Estonian companies. There were cases where Estonians founded firms for one season only; they founded the companies, completed the operations of the companies, closed down the companies and then came to the market with new companies the following year. The 
increased regulation in the Finnish construction labour market might have impaired possibilities for such strategising. A Rakennusliitto official (\#3) noted that Estonian firm owners have started realising the tighter control regime in the contemporary Finnish construction sector:

...these Estonian firms when they arrive, the main contractor has the liability to check... It needs to check everything. When a small company comes to carry out subcontracting, everything will be checked: how taxes are paid in Estonia, how the things with the workers have been dealt with. They now will understand that it's not that easy any more to try anything... If the Rakennusliitto hears about it, you'll immediately be boycotted. If you do subcontracting for XXX [a big Finnish company], it tells you directly to take your guys and return back to the other side [of the Gulf of Finland]. Nobody wants that any more. It was possible earlier.

This underscores the importance of monitoring the compliance according to the rules, not only by state authorities but also by trade union officials, in efforts to curb illegal business in construction. The tax numbers have also made Estonian employers straighten up their operations (Union official \#3). Also, the access control imposed as a part of the site register system has affected the situation. Estonian employers are under dual pressure: on the one hand, workers have realised that there is no reason to remain posted and instead it is better to pursue a regular employment relationship or to find a job in another country; on the other hand, employers are facing increasing bureaucratic pressures because of the new tax and inspection arrangements (Union official \#3). 
The change in the business environment is also noticed among our interviewees who are Estonian small-business owners. Kalev, who had a company doing welding work in construction, is a case in point in regard to the changing atmosphere. There were 11 employees working at his company; of whom two were Finns and the rest Estonians. Kalev had a positive attitude towards the new ID-card system and the measures implemented to prevent a grey economy in Finland. He deemed it as necessary on the part of the Finnish government to introduce such measures. Also, he gave the new 'construction site register' arrangement a positive assessment. He seemed to have internalised the sentiment that 'we' have to make sure that nobody should be able to work illegally in Finland.

Moreover, both Estonian unions and the Estonian Labour Inspectorate have put an emphasis on informing the public about worker posting. They have published pamphlets and conducted information days about posted workers' rights. The Estonian Labour Inspectorate also signed a cooperation agreement with the Finnish Occupational Safety and Health Administration (Töökeskkonna ülevaade 2014: 29). Furthermore, the Finnish Construction Trade Union established a department in Estonia, Tallinn, with the objective of informing Estonian construction workers that are working or planning to work in Finland about their rights there and to help if they encounter problems. Thus, the awareness about posting rules has probably increased in recent years both among workers and employers. Workers posted from Estonia have the right to turn to Estonian courts and the Labour Dispute Committee if they are mistreated, and there have been several cases where posted workers have gotten their lawfully earned wages through the verdicts of these institutions. 


\section{The Structure of the Finnish Migrant Labour Regime}

Grounded on our data, we argue that the pattern of firm ownership - referring both to the distinct division of labour between main contractors with Finnish ownership and subcontractors with Estonian ownership and to the migrant workers' relationship with and distance to the main contractor - is a major factor shaping the structure of the emerging migrant labour regime. We found that the nationality of ownership of the companies employing Estonians is an important determinant for the construction of the regime and consequently, for the position of the worker. Although this can be regarded as a 'natural' development (the Finnish firms tend to more readily implement the Finnish standards in their employment policy than the Estonian-originated companies do), this might also reflect the strategising of the main contractors and subcontractors around the 'translocal' labour market (Alho 2013).

We put forward four different positions (in terms of uncertainty and the level of wages) of workers in the Finnish migrant labour regime. The position of a posted worker is located in the bottom of the hierarchy; this is the position that Estonian workers would most eagerly like to get rid of (wages are the lowest and insecurity the highest). The position as a worker in an Estonian-owned company registered in Finland implies an improvement in terms of labour conditions compared to that of the posted worker. It is, however, evident that Estonian company owners are registering their business operations in Finland mostly for the sake of reputation in the eyes of Finnish contractors and not for the sake of providing better labour conditions for their workers. The third group, the self-employed and small business owners, consists of somewhat more privileged workers in terms of income and autonomy, but they are 
still precarious in terms of job security (there is no guarantee that work will continue; the responsibility for employment is completely on them). The fourth group, consisting of those workers employed in a Finnish company, is the one in which the workers are in the most secure position in terms of income, employment and rights. It would have been possible to distinguish those employed by Finnish temporary work agencies as a sub-category, since such workers have a distinctive position in the contracting chain, and they risk being employed for shorter time periods. However, we decided to include agency workers in the 'employed by Finnish companies' category, because migrants did not perceive it as considerably unfavourable to being employed by the Finnish construction company. It was argued that wages are good and paid according to the rules, regular working hours offered and employment contracts extended.

\section{Posted workers}

Although only one of the construction workers we interviewed was posted at the time of the interview, several of them had experiences of being posted during their earlier careers in Finland. The stories about being a posted worker indicated that these were difficult times characterised by uncertainty, poor working conditions and disputes with employees over unpaid wages. The following examples illustrate some aspects of this kind of working arrangement.

Aleksandr, who now worked for a scaffolding company owned by Estonians but registered in Finland, had previous experience of being posted from Estonia in 2010. In his words, the business idea of that company was 'to hire people for a certain job and then get new people in for the next job.' Aleksandr was, however, hesitant to share further details of the posting. He 
regarded himself as lucky because he later found a permanent job via a job advert; a job in which he has been for 3 years at the time of the interview. Jaan, Rein and Edgar did not complain about the levels of either working conditions (wages were not at the Finnish level, but they were not expecting Finnish salaries at that time) or living conditions at the time of being posted workers in Finland in the first decade of the 2000s. They seemed to regard that phase in their migrant work history as being almost a necessary part in a career path that eventually lead to permanent positions in Finnish firms. This indicates that those who are new in the Finnish labour market might accept staying at the bottom of the migrant labour regime until they gain more experience and knowledge about labour rights.

Arno, who was working as a posted worker 5 years before the interview, had more to complain about his treatment. He was employed by an Estonian agency firm that had an agreement with a Finnish agency firm on posting him to Finland. The wage, 8 euros, was paid into an Estonian bank account, and it 'was no wage at all, say, but at that time it was normal,' since the living costs in Estonia were lower. However, he coincidentally learned that the main contractor paid 34 euros per hour for him, which meant that the agency firms through which he worked at the site earned a high surplus. Arno decided to give notice of leaving the job the same day. Similar strategising between the contractor and subcontractors was seen in Lembit's story when he came to work for the first time in Finland in 2009. The Estonian company for which he was working did subcontracting for a Finnish construction firm. As a posted worker, he sought work directly from the Finnish main contractor, but he was informed that the Finnish main contractor had an agreement with the Estonian subcontractor: the former was not allowed to hire Estonians from the subcontracting firm. Finally, he managed to get a permanent job at a different Finnish contractor. Lembit 
considered that the typical way of entering into the Finnish labour market is via an Estonian construction company or agency firm:

As far as I know, there are many people who have come either through an Estonian firm or agency firm. First you get employed by an agency firm, and then you do good work somewhere and finally end up being employed by a Finnish company.

Moreover, Mart's story provides an example which shows that some Finnish firms still exploit the posting regime. He had been commuting between Finland and Estonia for almost 10 years, building houses for one firm and then for the last 8 years doing construction work for another Finnish firm through an Estonian temporary agency company. He had asked about the possibility to work directly for the Finnish firm, but the employer had said that it is not possible (because there are periods during which there is no work to offer). The Finns, in Mart's words: '...$/$ won't choose this option and for them it is easier to hire us through a rental company because then they don't have to pay us anything when they can't guarantee work for us.' Most optimally, he can have a schedule 2 weeks in Finland - 2 weeks in Estonia. With the agency firm, Mart does not have any clear-cut contract, and sometimes he has no work at all, but he is still satisfied: 'At least our wages are always paid on time, and the pay isn't small, it's more like average or above average compared to those Estonian firms who have workers in Finland.' As Mart argues, there is a real dependency relationship between the Estonian agency workers and the Finnish contractor: 'I think it makes more sense to talk about the company on the Finnish side, who we work for - there isn't much to say about the Estonian company, it just rents out workers.' However, the tight dependency relationship does not imply any responsibility on the part of the Finnish contractor: 
/.../ we are a rental workforce, we've been sitting at home for over a month now, there simply is no work at the moment. But it's really easy with a rental company or agency workers - if there's no work, the Finns have no responsibilities towards us.

The human resource strategy for the Finnish company Mart was working for seemed to be based on the following principle: permanent jobs for Finns, temporary agency jobs for Estonians. The Estonians, therefore, were the auxiliary workforce which is to be 'purchased' if need be.

Employed by a firm registered in Finland but operated by Estonians

Some accounts of the interviewed workers let us understand that there is a tendency that Estonian firms move from posting (of Estonian workers) to registering a company in Finland and then to employing Estonian workers. The reasons for this shift can be derived from both the concern for the reputation of Estonian companies in Finland and the stricter regulations in the Finnish construction sector. For example, Tom reported that the Finnish main contractors were not willing to subcontract purely Estonian firms any more. That is why the Estonian owner of the firm he was working for registered the firm in Finland.

Although the recent legislative changes had affected the situation, the Estonian firms were still able to circumvent the labour regime aimed at native workers. For instance, Peter, an interviewed Estonian worker who later became a Rakennusliitto official, regarded the tax number system as ineffective since the tax authority was not authorised to completely inspect 
working hours. Peter also maintained that it is easier for a Finnish contractor to deal with Estonian workers, since the former has no obligation to arrange fixed working hours or take financial - for example tax payment - responsibilities for the latter. The influx of cheap labour from Estonia has meant that the Finnish construction workers have had to accept lower hourly wages (which however are according to the construction collective bargaining agreement) instead of having higher contract-based wages. This is due to the pricing of the contracts below the Finnish standards by the Estonian firms. In Peter's view, Finnish companies were equally guilty for this development as main contractors.

The stories the migrants working for Estonian companies registered in Finland told us indicated that although through this kind of arrangement working conditions and wages might have been better than when posted, there were also several factors that remained 'Estonialike'. For example, long working hours resembled those of posted workers. Although Timo was locally employed in Finland, his work schedule hinted at an arrangement typical for posted workers: 3 weeks work in Finland, 1 week free time in Estonia. Another resemblance to the Estonian labour regime is that the Estonian employers did not generally allow their workers to belong to a union.

Similar patterns of irregularity and insecurity as in the case with posted workers were seen in Anti' story. He was generally unsatisfied with his position and considered working under Estonians as not being very beneficial for workers, as 'under Estonian management $[\ldots]$ the system is still like you are working in an Estonian company.' Anti was, however, unmotivated to change this arrangement due to his current flexible work schedule and to his ultimate plan to move back to Estonia. In the meantime he had to be flexible, as he did not have a permanent contract and there were breaks without any work between successive 
temporary contracts given by his employer. He had complementary job spells as a painter, a job he needed for the breaks when he was not offered any work. The introduction of the tax numbers had had some effect on the conduct of the Estonian employer, but there was still 'some kind of tricking' by the employer. The payment of the salary was often irregular. Anti felt himself to be bullied by the employer, when he found out that he was the last one to whom the employer paid the salary. This is a telling example of how the workers can be at the mercy of a single employer:

I knew that I am going to be paid, but it really got to me that I was the last one /.../ I do not believe that he [the manager] kind of, or directly thinks of me badly, but, but yes, he just, like he knows, that I will manage.

Valdo once worked for a company that was registered in Finland but that had Estonian owners and similarly to Anti he was very sceptical about Estonian employers in Finland: '...well, let's say $99 \%$ of the time, if you are working for Estonians then you either don't get paid or they don't pay you that ... you know, all the extras and things that you need for construction, you usually don't get that.' Valdo belonged to Rakennusliitto. He regarded the union as powerful enough to curb the illegal activities of Estonian companies:

But yeah, the Rakennusliitto, they can go to the workplace and stop a company from working, for example. They ban you and you can't work, for example. It happened to me once at a company. We went to work in the morning, the big boss from the main contractor came and said ... the guys from XXX [A Finnish company with Estonian ownership] ... you are not allowed to work in Finland. So you can't work. Go home. 
Valdo told, however, that the boycott imposed by the Rakennusliitto and the ban on business operations imposed by the authorities did not prohibit the company owners from establishing a new company with a different name and starting operations again in Finland.

Evert's story illustrates how the Estonian construction business arranges its human resource policy in a way which is beneficial for Finnish contractors. He was employed by a middlesized Estonian construction company (with around 100 employees), in which almost all of the workers were Estonians. The company did subcontracting for major Finnish construction companies in the biggest Finnish towns. He mentioned that he had applied for work for a Finnish main contractor (for whom they did subcontracting) a couple of times. The fact that the main contractor refused to hire the Estonian (subcontracting/agency) firm's workers bears resemblance to Lembit's story (see 'Posted workers' section). When applying for a job the first time, Evert did not even receive a reply because the company - as he was told - did not need any workers; however, that company had a new Finnish worker hired the following week.

\section{Self-employed and small business owners}

On the basis our analysis, we regard that being a self-employed service provider or a small business owner might provide better labour conditions for Estonians in the Finnish migrant labour regime than the statuses of being a posted worker or employed at Estonian-owned companies registered in Finland. First and foremost, it is manifested in better remuneration and a higher degree of autonomy, although in regard to employment security this kind of position is less secure and predictable than being employed by a 'real' Finnish company. It is 
also to be noted that certain Estonian owners of construction companies are in comparatively advantageous positions (they sometimes exploit their co-nationals), but those are beyond the scope of this article as they represent the position of managers or employers rather than that of workers.

Veiko had established a small firm of his own. Through his company, he provided his services in the construction sector in both Estonia and Finland. The idea of establishing the company derived from the seasonality of his earlier job spells in Finland; typically he worked from March-April until November-December, and then he was sent on unpaid holiday. So far, however, the emphasis of his business activity had been in Estonia, and there had been only a few contracts in Finland. He acknowledged that working in Finland is project-based and seasonal; however, he did not seek more secure, long-term commitments. As an Estonian employer in the Finnish market, Veiko saw the pros of the well-regulated Finnish system, although foreign contractors were undermining it. Veiko's account, therefore, reflects awareness of the positive side of regulation on the one hand, but also acknowledgement of the fact that a foreign employer can circumvent institutional constraints on the other:

In many respects, the system like this is good. When you [the employee] achieve a certain level, you see that you are supposed to have such a wage. But the market puts everything in place $[\ldots]$ one told me that their firm does not get contracts anymore, because Estonians and other foreigners have put the market price at a low level. There is, indeed, quite tight competition in that respect.

Arno, who was currently working in a Finnish firm, also pondered the pros and cons of entrepreneurship. Some of the colleagues with whom he used to work in Estonia were self- 
employed in Finland. They appeared to have a better income than Arno. While his net earnings per hour were 13 Euros, he argued that as a self-employed person he could get 22 Euros, minus taxes and other costs. However, Arno maintained, the main contractor had no responsibility for a self-employed person. Were he 10 years younger, he would consider becoming self-employed. He was also aware of the downside of being employed by himself: 'there wouldn't be any work in the wintertime.'

The difference between the statuses of being self-employed and a wage-earner is seen in the fate of three fellow workers, Jaan, Rein and Edgar. Jaan had worked in Finland for 7 years, whereas Rein and Edgar had only worked for 3 years. The status of the workers was different in the first round of the interviews in 2014: while Jaan had an enterprise of his own, based in Estonia, Rein and Edgar had been directly employed by a Finnish company since summer 2013. For some reason Jaan had not got a permanent position, as the other two had, although he was working for the same Finnish contractor. In fact, the company owner (a Finn) tried his best to persuade Rein and Edgar to establish a firm of their own, but as they delayed their decision, the owner eventually agreed to employ them directly. Rein concluded that 'it would be easier [for the Finnish owner] to get rid [of me] if I had a firm of my own. But now I am satisfied.' The structure of the small construction company, for which Jaan, Rein and Edgar worked, actually consisted of a web of several smaller companies in which 'everyone came up with a firm of their own.'

\section{Employed by a Finnish firm}

Working for a 'real' Finnish company, even if only a temporary agency firm, was seen as something desirable but hard to achieve by several of our interviewees. Despite his 
employment as an agency worker, Vello was quite satisfied with his position as carpenter at one of the biggest Finnish labour agency firms. Although he did not have a carpenter's degree in Estonia, he was given a salary corresponding to a carpenter's qualification. However, the work was hard, and he was interested in educating himself to do a less-demanding occupation, such as that of a crane driver. Vello realised there would be better paid positions in other firms, but he was afraid of changing the job because there would be a 4-month probation period during which the employer could dismiss him at any time. He had tried to get onto courses to get educated as a crane driver, but his employer (the Finnish labour agency firm) had refused to pay for that. He considered that this was odd: the company would benefit from his higher qualification.

After having been employed by the same Finnish agency firm as Vello, Arno had managed to get a permanent job at a 'real' Finnish construction firm. He worked as an excavator driver. The difference between these two workers seemed to have been that Arno had the required qualifications already when coming to work in Finland, whereas Vello had just started to pursue a higher qualification. Arno clearly saw the pros of being employed by a Finnish employer: 'Well, he pays the salaries, and... working hours are at 8 hours a day, you are at home on Saturdays and Sundays and nobody forces you to work more than that.' In the current firm, Arno worked without a written employment contract, or at least he had not seen the contract. However, 'the salary has always been put onto the account.'

The fact that Jaan, Rein and Edgar have worked for the same Finnish employer for a few years might indicate that they have found secure employment. On the other hand, they might not have any other option, that is, any other place to go; all of them would have liked to get a job within a $200 \mathrm{~km}$ radius of Helsinki but have not succeeded so far. Even though they had 
been working as a team for years, basically doing contract work for the owner of the company, they were persuaded to become self-employed. All agreed that the boss was 'bad tempered' sometimes, even though they had done a good job. Moreover, even if a Finnish employer hires Estonians it might be because they are not as demanding as locals, but rather 'good workers' in the eyes of the employer (MacKenzie \& Forde 2009), as Anti concludes:

They [Finnish employers] do hire [Estonians] if you are able to prove yourself, then I believe, they do hire you. Well, I think, that... that it is possible to pay a minimum rate to Estonians. Well, I do not know, we do a lot of demolition work that Finns do not want to do, and as such some Finnish company will gladly hire Estonians. Firstly, they do not have to pay as much since who is working is working for less money. I do not know, I don't know any Estonian currently who is being paid as much as a Finn. Well, I do not know about numbers, but I am rather sure, that no Estonian, perhaps some highly skilled specialist is getting paid as much... but I doubt it $[\ldots]$.

Lembit, who worked for a Finnish construction firm had noticed the racism that prevails on Finnish construction sites. According to him, Finns do not regard Estonian colleagues 'as their own', and the former are likely to exclude the latter:

Well, it [the racism] appears in wages, labour relations, but going to work is also very bad when... Like we were, went to work, took our clothes off, put them in the closet and took our shoes off. Then men [Finnish co-workers] would come and take them and throw your shoes into the dustbin, for example. /.../ Or they would come and yell at you. /.../ 
Lembit related this kind of behaviour to the fear of Finns that foreign workers would either take their jobs or that the Finnish workers would not be able to be 'as lazy' anymore while working. The accounts of the interviewed Estonian construction workers were uniform in arguing that Estonians tend to be more flexible and hard-working than locals and thus 'good workers' (MacKenzie \& Forde 2009). Arno was similarly as sceptical as Lembit of the possibility of becoming culturally and economically equal to local workers either in the eyes of Finnish co-workers or Finnish employers.

All this seems to be evidence that despite the Estonian workers' ability to climb up the career ladder up to the position of 'employed by Finns', they still seem to be locked in a less favourable position than the native workers. There seems to be, however, an exception to the rule, which is Dagmar's story. Dagmar's story of getting a job in Finland is exceptional, since he got it through a trade union contact in Finland while being a trade union activist in Estonia at the beginning of the 2000s. He called the employer and asked for a job and got an affirmative response. In his words, the employer appeared to be benevolent especially to those foreign workers who had been fired by other (dishonest) employers in Finland. The employer had also a positive attitude towards the trade union membership of the workers.

\section{Concluding discussion}

The aim of this analysis has been firstly to throw light on the drivers of regulation that lie behind the emergent migrant labour regime in the construction sector in Finland. Although employer and labour strategies are important in shaping the regime, the roles of EU (e.g., through different directives) and government regulation, which are influenced by social 
partner institutions, remain crucial. There are clear signs indicating that the policies of the Finnish government alongside trade union efforts and lobbying activities (sometimes in cooperation with the employers' federation) have had a positive overall effect on the evolvement of the construction labour market. Thus, a strong industrial relation system such as that in place in Finland seems to be more resistant to the corroding effects of postaccession labour migration than other systems; even within the single EU labour market. The Finnish government, in contrast to the effects seen elsewhere, has been able to deter the undermining of the strong industrial relations system in construction (Wagner \& Lillie 2014). Further research is needed in different sectors and national contexts to analyse whether also alternative ways of circumventing institutional constraints at the national level (Herrmann 2008; Lillie \& Sippola 2011) can be prevented by interventionist regulation and cooperation between authorities at the national and international level.

Secondly, we have explored the current migrant labour regime apparent in the Finnish construction sector. We have identified four differing positions within the regime: posted workers; those working for a company registered in Finland but owned by Estonians; selfemployed or small business owners; and those working for a 'real' Finnish company. We have seen that the pattern of firm ownership - reflecting both the nationality-based division between the main contractors and subcontractors and the workers' relationship with and distance from the main contractor - is a major factor shaping the structure of the emerging migrant labour regime. The translocal labour market setting that has emerged between Estonia and Finland has generated different worker positions based on their employers' nationality, the relationship to the main contractor and workers' contractual status that reinforces the segmentation of labour. 
This study further reveals that irrespective of employer strategies, the Estonian workers had managed to improve their position through hard work and lucky coincidences, partially rendered possible by the recent development of labour market regulations. There is indeed a variety of forms of the use of labour, and the position of migrant workers might have improved compared to that of posted workers. However, the migrants still do not regard themselves as 'full' members of the labour collective. Although the analysis showed marked differences between the four positions in the construction labour market - the first position (the posted workers) being most and the fourth position (those working for a Finnish company) being the least precarious and low-paid - the whole migrant labour regime seems to be based on the inferiority of the Estonians. It is remarkable that the Estonians were still in a more disadvantageous position in terms of career advancement, cultural acceptance by locals, dependency on the employer and flexibility demanded from the side of the employer. Moreover, the expectation of the employers that Estonians tend to be more flexible workers than locals often persisted even though the employer was not any more an Estonian. Whether this is due to the overall deterioration of the position of the workers in the Finnish construction sector or to a systematic tendency of segregation in the labour market remains a question to be considered in future research.

By means of the biographical lens, this study suggests that migrant workers' agency also plays a role in shaping the migrant labour regime. Seemingly, these Estonian workers desired to leave their precarious positions behind and enter the ranks of fully respected and valued worker-citizens (see e.g. Anderson 2013) by seeking employment in 'real' Finnish firms. However, the Estonians appeared to seek improvement in their positions via becoming 'good workers' (MacKenzie \& Forde 2009) - referring to qualities attributed to workers by employers - rather than demanding their rights as workers per se. Thereby, migrant workers 
were on the one hand able to gain a 'competitive advantage' over local labour and to secure employment, but on the other hand, they simultaneously consented to inferior employment conditions in comparison to natives. Analysis of different forms of workers' individual and collective agency was beyond the scope of this study but is an important aspect that ought to be scrutinised in further research.

\section{Acknowledgments}

This research was funded within the framework of Academy of Finland project 'Industrial Citizenship and Labour Mobility in the EU: A Migrant Centered Study of Estonia-Finland and Albania-Italy Labour Mobility', which was funded by the Research Council for Culture and Society (Principal Investigator Dr. Nathan Lillie) and the Estonian Ministry of Education and Research funded project 'Alternatives at Work and Work Organisation: Flexible Postsocialist Societies' (Principal Investigator Dr. Triin Roosalu). We would also like to thank two anonymous reviewers and editors of this issue, Line Eldring and Jon Erik Dolvik, for their helpful comments and suggestions. 


\section{References}

Alho, R. (2013). Trade union responses to transnational labour mobility in the FinnishEstonian context. Nordic Journal of Working Life Studies, 3(3), 133-153.

Anderson, B. (2013). Us and them?: The dangerous politics of immigration control. OUP Oxford.

Berntsen, L., \& Lillie, N. (2016). Hyper-mobile migrant workers and Dutch trade union representation strategies at the Eemshaven construction sites. Economic and Industrial Democracy, 37(1), 171-187.

Colic-Peisker, V., \& Tilbury, F. (2006). Employment niches for recent refugees: Segmented labour market in twenty-first century Australia. Journal of Refugee Studies, 19(2), 203-229.

Ebbinghaus, B. (2004). The changing union and bargaining landscape: union concentration and collective bargaining trends. Industrial Relations Journal, 35(6), 574-587.

Eldring, L. (2011) 'Posted workers in Norway: Win-win or lose-lose?' CLR News 1/2011, $10-25$.

Eldring, L., Fitzgerald, I., \& Arnholtz, J. (2012). Post-accession migration in construction and trade union responses in Denmark, Norway and the UK. European Journal of Industrial Relations, 18(1), 21-36. 
Elvander, N. (2002). The labour market regimes in the Nordic countries: A comparative analysis. Scandinavian Political Studies, 25(2), 117-137.

Fan, C. C. (2002). The elite, the natives, and the outsiders: Migration and labor market segmentation in urban China. Annals of the Association of American Geographers, 92(1), 103-124.

Friberg, J. H. (2012). Culture at work: Polish migrants in the ethnic division of labour on Norwegian construction sites. Ethnic and Racial Studies, 35(11), 1914-1933.

Friberg, J. H., Arnholtz, J., Elding, L., Hansen, N. W., \& Thorarins, F. (2013). PART II: Labour market regulation, migrant workers and varieties of "social dumping" in Oslo, Copenhagen and Reykjavik. Friberg, J.H. \& Eldring, L. (eds.). Labour migrants from Central and Eastern Europe in the Nordic countries. Patterns of migration, working conditions and recruitment practices. TemaNord 2013:570, pp. 43-58.

Herrmann, A. M. (2008). Rethinking the link between labour market flexibility and corporate competitiveness: a critique of the institutionalist literature. Socio-Economic Review, 6(4), 637-669.

Kalleberg, A. L. (2009). Precarious work, insecure workers: Employment relations in transition. American Sociological Review, 74(1), 1-22.

Lillie, N., \& Sippola, M. (2011). National unions and transnational workers: the case of Olkiluoto 3, Finland. Work, Employment \& Society, 25(2), 292-308. 
MacKenzie, R., \& Forde, C. (2009). The rhetoric of the good worker' versus the realities of employers' use and the experiences of migrant workers. Work, Employment \& Society, 23(1), 142-159.

Meardi, G., Martín, A., \& Riera, M. L. (2012). Constructing uncertainty: Unions and migrant labour in construction in Spain and the UK. Journal of Industrial Relations, 54(1), 5-21.

Piore, M. J. (2008 [1979]). Birds of passage: migrant labor and industrial societies. Cambridge etc: Cambridge University Press.

Schütze, F. (2005). Cognitive figures of autobiographical extempore narration. Biographical Research Methods, 289-338.

Sippola, M. (2012). The restructuring of the Nordic labour process and the variegated status of workers in the labour market. Competition \& Change, 16(3), 243-260.

Sippola, M. (2013). The awkward choices facing the Baltic Worker: exit or loyalty. Journal of Baltic Studies, 44(4), 451-473.

Sippola, M. (2015). The Finnish labour market model: Collective agreements versus legislation in a perspective of goals and values. In: De Nordiske Arbejdsmarkedsmodeller I Global Konkurrence. Copenhagen: Foreningen Norden, 21-31. Available at: http://detnordiskearbejdsmarked.org/wp-content/uploads/rapport-de_nordiske_arb1.pdf 
Social Insurance Board. (2015). Republic of Estonia Social Insurance Board homepage.

Statistics about issuing A1 certificates. Available at:

http://www.sotsiaalkindlustusamet.ee/vormi-e101-valjastamine/

Statistics Finland. (2013). Every fifth office cleaner of foreign origin in 2011. Available at: https://www.stat.fi/til/tyokay/2011/04/tyokay_2011_04_2013-11-06 tie 001_en.html

Töökeskkonna ülevaade. (2014). Töökeskkonna ülevaade 2014. Tallinn: Tööinspektsioon. Available at:

http://www.ti.ee/fileadmin/user upload/failid/dokumendid/Meedia ja statistika/Toeoekeskko $\underline{\text { nna uelevaated/2014/2014_Tookeskkonna_ylevaade.pdf }}$

Wagner, I., \& Lillie, N. (2014). European integration and the disembedding of labour market regulation: transnational labour relations at the European Central Bank construction site. JCMS: Journal of Common Market Studies, 52(2), 403-419.

Wills, J., May, J., Datta, K., Evans, Y., Herbert, J., \& McIlwaine, C. (2009). London's migrant division of labour. European Urban and Regional Studies, 16(3), 257-271. 